\title{
FEATURES OF THE STATE REGULATION OF THE PRODUCTION OF GENETICALLY MODIFIED PRODUCTS IN THE WORLD AND IN UKRAINE
}

\author{
Viktoriya BASHUK ${ }^{1}$ \\ Ivan Franko National University of Lviv, Ukraine
}

\begin{abstract}
The purpose of this article is to investigate the regulation of the use, consumption, and trade of genetically modified organisms in different countries of the world, as well as in Ukraine. The definition of international approaches to risk assessment of genetically modified products is of particular importance for international trade. Methodology. The study is based on data from different sources, beginning with the first mention of genetically modified organisms, ending with the latest received data from different countries. Purpose. Show how different countries refer differently to the production of genetically modified products, differently perceive it and are guided by different principles. Find ways to solve the problems associated with the introduction of GMOs in Ukraine and compare them with other countries. Results. The study showed that developed countries have developed clear rules for the production, labelling, consumption, and trade of products containing GMOs. Also, the bodies and structures responsible for compliance with all these rules are defined and a large number of legislative acts has been adopted, which cannot be said of Ukraine. In Ukraine, this is a large gap because "on paper" also seems that there are some rules according to GMOs but they are not clear, consistent, and they are not followed due to their observance, as these powers are entrusted to a large number of structures. Due to imperfect legislation and lack of funds, products that are imported are not tested for GMOs content, there are no studies on the safety of their consumption and cultivation, the reliability of information on labels is not followed. Practical implications. In Ukraine, in order to ensure the proper level of state regulation, protection, and use of genetically modified products obtained with the help of modern biotechnologies, it is necessary to adhere strictly to the fulfilment of the main criteria: 1) adoption and further improvement of legislation regulating this area of activity; 2) registration and prevention of the danger of genetic pollution of the environment as a result of the production of genetically modified products; 3) determination of economic efficiency from growing GM plants; 4) introduction of a transparent GMO registration system and issuing permits for field testing of transgenic plants, limiting plant testing to several years; 5) solution of a problem of intellectual property protection in this area and technology transfer; 6) determining the degree of influence of genetically modified products on human health and the biosystem as a whole; 7) formation of public opinion, development of environmental education; 8) enhancement of international cooperation in plant biotechnology and biosafety. Value/originality. Ukraine is a big country that is developing, it has a good potential and can get economic benefits from the production of genetically modified products, so it is necessary to fill in all the gaps in this matter in the near future in order to take its place in this sphere.
\end{abstract}

Key words: genetically modified organisms (GMOs), genetically modified products, trade regulation, regulation of using GMOs, Ukraine.

JEL Classification: Q16, Q16, F10, Q17, H70

\section{Introduction}

Using of genetically modified organisms (GMO) have provoked a serious debate in the majority of industries. Scientists from different countries have diverging views of making products with GMO. The same opposite views have formed on trading with such products. The definition of international approaches to the risk assessment of genetically modified products has a particular importance to international trade. The establishments of barriers in international trade of food products with GMO can be the main obstacles, which are contrary to the principles and objectives of free trade embodied by the world trade organization (WTO). Ukrainian scientists also shared their opinions about the cultivation and consumption of GM products. 


\section{GMO trade regulation within WTO}

Countries that are WTO members covered under the agreements within this organization. According to these agreements, lawful measures will be those (first of these is on sanitary and phytosanitary measures) that meet certain international standards, guidelines, or recommendations and are deemed necessary to protect the life or health of humans, animals and plants and thus are regarded as relevant Agreements of using sanitary and phytosanitary measures (SPS) and General agreement on tariffs and trade (GATT) of 1994.

None provisions of the GATT-1994 don't oblige member-state of WTO to cultivate GM crops on their territory and WTO rules can be used only for trade in goods between countries. The vast majority of trade rules, which are used by importing countries, are limiting. Thus, the basic rules of GATT-1994 can be applied also to import of GMOs. In accordance with the regulations of the Agreement on SPS, any measures of the WTO state members in the issue of imports, including products from GMOs, must be based on scientific principles and are not supposed to remain in force without sufficient scientific justification. As soon as the GM product is imported into a specific country, its distribution is regulated by national legislation (Volkov, 2014).

\section{International regulatory acts which govern using GMO}

Nowadays production, turnover, and using of GMO is regulated by such international regulations as: Convention on Biodiversity, Rio de Janeiro, 5 June 1995; Cartagena Protocol on Biological Security to Convention on Biodiversity Montreal (Canada), 29 January 2000; Codex Alimentarius 1999, Convention on "Access to Information, Public Participation in Decision-Making Process and Access to Justice on Issues Concerning Environment”, Orgus (Denmark), June 1998.

Authorities in many countries of the world purposefully support the development of modern biotechnologies as an important labour force, the growth of economics, an increase of welfare of the population, and improve the competitiveness of their (national) production (Dromashko, 2011).

Each country has its own attitude to the GMP but we can distinguish at least two opposite positions regarding using this product: first, the so-called American point of view is based on the active support and extensive use and export of transgenic crops; the second attitude (European) is more critical (Lozinska, 2009).

\section{Regulation of using GMO in the USA}

The American approach to the genetically modified organisms is based on the product rather than on production process and considers biotechnology as secure is inherently and its products how such are do not differ from unmodified analogues. As the result, US government hasn't adopted any specific law on GMOs and there still using a legislation, which was adopted for usual products. Thus, GMOs is regulated by the Law on Plant Protection, Federal Law on Food Products, Drugs and Cosmetics, Federal Law on Insecticides, Fungicides and Rodenticides and Law on Control of Toxic Substances (Balasynovich \& Iaroshevska, 2010).

In the USA, the issue of GMOs regulation lies within the competence of the Management on Sanitary Inspection behind Quality of Food and Drugs of the USA (FDA), Department of Agriculture (USDA) and Agency for the Protection of the United States Environment (EPA). The distinction of their forces is estimated by the Federal system for regulation of biotechnology, which has been in force since 1986 (Balasynovich \& Iaroshevska, 2010). There are (in the USA) no specific requirements for marking of GMO products, as a separate class of foodstuffs because GMO products are not considered less safe rather than usual foodstuffs. However, GMO products are subject to standards of binding marking, which require marking of any products, which are led to particular risks for health and environment. It can be, for instance, the presence of an allergen or change of food properties. American experts believe that the licensing exhaust system of GMO in the market is complemented by the tight control at the stage of production of new products with special requirements to the research results of each modified protein is quite effective.

Orientation on the final product while elaboration of national measures in the area of market regulation suggests using the principle of notification, which is carried out by informing regulatory authorities about the implemented modifications by the manufacturer of a new product. According to the decision of these bodies, the goods may be admitted to the market on a common basis without additional inspection or after inspection and the issuance of a special permit. All of this information is available to society on the basis of the Law $\ll$ On Freedom of Access to Information».

\section{Regulation of using GMO in Canada}

Canada is a country with a high development level of agricultural biotechnology, which applies a control system. It has a developed system of regulation of markets for new products and feeds. But this system, as in the other countries, is not perfect and falls under the influence of varying factors. Back in 1993, the government of Canada adopted the "Main Directions of Federal Regulation of Production and Turnover of Biological Products". The main objective of this document is to ensure safety supply of high income for human health and the environment by the implementing 
of biotechnology products. This document contains the basic principles of national policy in this area.

The main legislative acts in the field of state administration are the Laws «On Food and Drugs», $\ll$ On Feeds $», \ll O$ On Seeds $»$ and a large number of bylaws. In Canada, the functions of regulation and control over commercial use of new food products are entrusted to the Ministry of Health, Ministry of Environmental Protection and the Agency for Control over the Foodstuffs.

It is also noteworthy that for Canadian system, a gradual procedure of production regulation and turnover of new foodstuffs is common. Under the category of new food products, according to Canadian law, a significant number of products are subject to it. The mechanism of sale regulation of new products involves three stages: pre-market notification, premarket approval, and a system of food-processing standards (Stepnova \& Berlova, 2007).

Despite the existence of efficient control system, since 2000 under the influence of new scientific data about GMOs and under the pressure of public opinion in Canada, as well as in the United States, there has been a definite change in the approach to control of new food products. In general terms, it boils down to the following key points:

- recognition on the federal level of a necessity for voluntary marking not only organic but also GM-products;

- assumption of the development of mandatory marking of some new products;

- possibility of a moratorium on commercial turnover such GMOs, that risk of which (when it can fall into the environment) at this stage of the development of science is difficult to assess;

- requirement of recognition as not scientifically proven widespread principle of «stable equivalence» of new products in the USA and Canada;

- need for reducing the level of secret research and development, despite the existing regulations regarding the protection of intellectual property rights.

\section{Regulation of using GMO in Argentina and Brazil}

There is another state, «mega-countries» keen on growing GM crops is Argentina, which area is covered by them over 23.9 million hectares, and the regulation over GMOs is based on the control flow of product but not on the production technology.

At the early stage of formation, the regulation system of GM crops in Argentina was too similar to the same system in the United States. But the flexibility, rationality, and a scientific approach are the main principles of this system, which allow adjusting the rules in accordance with the new scientific evidence about biosafety of GM crops.
Based on a series of resolutions in 1991, the Secretariat of Agriculture, Fisheries, Food and Livestock of Argentina controls a large number of transgenic crops. In accordance with the requirements of the resolutions, three different departments are responsible for the registration:

- National Advisory Commission on Agricultural Biotechnology, "CONABIA" is responsible for scientific assessment, technical release, and influence on the environment. This commission is a multidisciplinary between-institute consulting group on biotechnological assessment. The Commission provides a consulting technical support and control in the area of biosafety and about questions of production of transgenic material into the environment.

- National Agrifood Health and Quality Service, "SENASA" with the help of technical consulting group regulates GMOs food security.

- National Directorate of Agrifood Markets, "DNMA", which is responsible for the assessment of the potential influence of commercial GMO on the market for goods (Iakovleva, Vinogradova \& Kamionskaia, 2015).

It should also highlight such a powerful producer of genetically modified products as Brazil. The first Law on Biosafety entered into force in Brazil in 1995 and was replaced in 2005 by a new one. Until like any GM plant will get into a field, all the risks had assessed, which are related to production into the environment, including potential harm to human health and other organisms. If a GM plant does not pose a potential threat, it is entitled to its field production but it has to be comprehensively tested, including the research of the possible influence on the environment. The right to commercial using of GM crops in Brazil is also provided to the National Technical Commission on Biosafety (CTNBio) (Iakovleva, Vinogradova \& Kamionskaia, 2015).

A law since 2005 in Brazil actually legalized GM crops. There was also established a national Council on Biosafety, the competence of which includes the analysis of socio-economic risks of GMOs and the National Technical Commission on Biosafety, which defines the technical aspects in this field. In February 2008, in Brazil two varieties of GM maize were permitted for commercial use: insect-resistant MON 810 and Liberty Link Bayer CropScience herbicide tolerant glufosinate ammonium (Balasynovich \& Iaroshevska, 2010).

\section{Regulation of producing and turnover of GMO in the EU}

In contrast to the American regulation system of production and turnover of genetically modified products, there is the so-called «European model of state regulation of genetically modified products $\gg$.

About active inclusion to the competition on the biotechnology market of EU countries is evidenced the fact that countries such as Germany, France, and 
Britain are increasingly investing in the establishment of biotechnology companies. For example, EU companies, going by joining into large enterprises, have created the world's largest biotech corporations Syngenta and Aventis.

However, softening of the EU position relating to the GMOs is accompanied by the formulation of clear rules for GMOs turnover, which provide the possibility of their identification by consumers, in particular, was introduced mandatory marking of products containing GM components (Lozinska, 2009).

The European Union is considering genetically modified organisms as the result of a special production process. Therefore, there was developed a special system with rules of conduct with GMOs, which entered into force in the beginning of 90-es. Until 2004, was acted in an unofficial moratorium on approving new GMOs in the EU. Under the pressure from trading partners, especially the United States, in 2004, the EU replaced the moratorium on the revised regulatory system, which covers the security matters, GMO marking and tracking, having created the most rigid code of laws about GMOs in the world. Only approved GMOs can be placed on the market in the EU (including imports).

Each case must be considered separately. The approval and permitting procedures is very complex and require the participation of all member countries of the EU because, in the case of approval, such GMOs can be placed in all 27 national markets of the membercountries of the EU over the next 10 years.

Till today, the EU has remained two-level regulation of all operations with GMO's: national and pan-European. In the field research of new GM crops, national standards are applied, for commercial use it must comply with both national and international regulations (standards).

In 1997, the European Commission has developed regulations in the EU for production and trade of new foodstuffs and their ingredients. According to this document, all products in the EU must be tested and marked before their supply to the market, and all products containing GMOs must meet standards that ensure food safety for the population and environmental protection. It was a necessary condition for their commercial turnover.

The implementation of the principle of tracking allows us to monitor all effects of the GMO on human health and the environment, to check the correct marking, and also gives a possibility to withdraw the goods from commercial turnover in case of revealing of the negative consequences of their use. Thus, information about the presence of GMOs in the goods is available to all market participants and it can be kept for five years from the start of use of each product.

All certified and admitted to the commercial use GM-products must be marked and entered in a special register, the same for foodstuffs and feeds. Based on the fact that currently there are no absolutely pure products, new EU rules allow the accidental existence of GM impurities in certain batches of foodstuffs and feeds but no more than $1 \%$ (Stepnova \& Berlova, 2007).

The EU has imposed strict mandatory marking rules, and its system is based on the production process, not only on the product, and includes a wide range of products with few exceptions and very low threshold. Furthermore, in the countries-members of the EU, voluntary rules of marking products without GMOs are operating.

In relation to access to the EU market, if GMOs are not allowed the EU which was found in the party of the imported goods, the EU could apply protective measures, starting with additional testing requirements and certification and ending with a temporary cessation of the import of the problematic product. In the case, if the shipment contains GMOs but only those that were allowed in the EU, they must be marked in an appropriate way.

It is noteworthy that in the EU, the concept of «coexistence» meant not only a spatial separation of places of cultivation and processing of organic, traditional, and GM farming but the application of the system of product traceability throughout the production chain «from farm to spoon». New EU Recommendation is true carry the question of establishing «buffer zones» around the industries associated with the processing and obtaining of products containing GMOs at the regional level, which can be competently considered characteristics such as variability of natural and climatic conditions, volumes and field sizes, topographic characteristics of the area, the terrain, the crop species features, and agriculture management specificities.

The regulation should include an assessment of each new GM crops by strictly regulated criteria and possible detrimental effects on the environment and should determine the potential risk in each specific case, by installing, if it's necessary, measures to limit risk and control.

\section{Problems of the state regulation of the GMO market in Ukraine}

Scientists of Ukraine are divided into two camps: those who are associated with GMO producers, of course, are against labelling GM products because they receive grants from foreign corporations, this is their «bread». The second group of scientists defends another position. They are not against GMOs and genetic engineering but they want everything to be clean and open. This is certainly progress in science (Makarovskaya, 2008).

If practically the whole world studies transgenic organisms, getting new plant varieties, then in Ukraine it is possible to introduce them, say technically, to grow rapeseed with a high oil content, which is used as an 
environmentally friendly fuel or there is an opportunity to present Ukraine as a country whose products don't contain GMOs, thereby affirming their authority in Europe and the world (Koval, 2007). However, one should not make categorical conclusions that in our state research work on the use of GMOs should be prohibited (but with appropriate restrictions). After all, stopping it completely, the domestic science can lag behind the world science, in particular from the European one.

It is pertinent to recall that Ukraine isn't a newcomer in the field of creating transgenic plants. Fundamentals of genetic engineering of plants were laid in the institutions of the National Academy of Sciences of Ukraine and the Odessa Institute of Selection and Genetics in the 70s of the last century. It was these sources that determined the intensive development of genetic engineering of plants in Ukraine in the mid-1980s, as a result of which the Institute of Cell Biology and Genetic Engineering was founded in the 1990 year.

At the current stage of the work of NAS, scientists are coordinated within the framework of the basic research program $\ll$ Genetic and Cellular Engineering as the basis of the «green revolution» in plant growing» (20022006) (Blum, Sivolap, Rydiy \& Sozinov, 2006).

Food products produced in Ukraine with the help of modern biotechnology can be classified into the following categories:

1. Foods consisting of living viable organisms or containing chemicals, such as corn.

2. Foods isolated from GMOs or containing ingredients that are isolated from GMOs, for example, flour, food proteins or oil obtained from GM soy.

3. Foods containing individual ingredients or additives, synthesized by GM microorganisms (GMM), for example, dyes, vitamins, and essential amino acids.

4. Products containing ingredients treated with enzymes that are synthesized with petroleum products, for example, high fructose corn syrup, made from starch with a glucose isomerase enzyme (Iulevich, Kovtun \& Gil, 2012).

British PG Economics together with the Ukrainian Institute of Food Biotechnology and Genomics estimated the possible economic effect from the introduction of GM technologies in the Ukrainian agrarian sector. In particular, the introduction of GM seeds for seedlings can increase the country's annual income by $\$ 525$ million. Agricultural biotechnologies, if they are authorized for the use in Ukrainian farms, will provide a noticeable economic and food benefit, raise the profitability of farms and reduce risks. The environment also improves as farmers start using softer herbicides, and insecticides replace insect-resistant crop lines (Brooks \& Blum, 2012).

Scientists suggest using GM technology for growing four traditional crops - soybeans, corn, rapeseed, and sugar beet. Moreover, it is proposed to take such GM plant varieties, resistant to herbicides, and corn - also to certain types of insect pests. Despite the total ban on the use of genetically modified varieties of plants in Ukraine, most of the soybean in Ukraine is grown using herbicide-tolerant technology. In addition, in Ukraine, maize varieties resistant to various pests are used. There are several economically sound arguments regarding the legalization of GM technologies in Ukraine. According to experts, their use should increase the yield and, accordingly, increase the gross yield. For four basic crops, the profit will be from 1.5 to $9.5 \%$. The use of herbicides in the care of them will be reduced by $4.4-7.8 \%$. As a result of the use of tolerant herbicides GM crops, the effect of herbicides on the environment will be reduced by $15-24 \%$. Reducing the number of treatments with pesticides will save from 0.78 to $150000 \mathrm{l}$ of fuel; to the atmosphere will be emitted less carbon dioxide - from 2.73 to 5.05 million $\mathrm{kg}$ (Brooks \& Blum, 2012).

However, it should be noted that products with GMOs in Ukraine are not officially grown.

It should also be noted that today in Ukraine there is no single state body that would deal with GMO issues. In accordance with the Law on Biosafety, powers for control and regulation are dispersed between five executive bodies: the Cabinet of Ministers, the Ministry of Education and Science, the Ministry of Environmental Protection, the Ministry of Health, and the Ministry of Agrarian Policy.

For Ukraine, this problem is also extremely relevant because no one checks what is imported into the country. There is a real threat to become a dump of genetically modified rubbish, which doesn't comply with the European standards. The legislative base seems to exist, there is a permission to sell products with GMOs with mandatory marking but there is no control because there is a catastrophic lack of funds to implement the regulations. There is a serious danger of becoming economically dependent on GM-producing companies because they, as owners, have the exclusive right to sell and distribute seed material, and they charge huge fines for unauthorized use. But the greatest harm can be incurred by the environment. The modified genetic material contains in plant remains, gets into the soil, adversely affect it. In addition, signs of GM plants, for example, resistance to herbicides, can also acquire weeds.

So, since no GM culture in Ukraine is officially registered, their importation to Ukraine and cultivation are illegal. However, Ukraine's agriculture is not free from GMOs. GMOs get to food products in Ukraine mainly from agricultural raw materials, imported to Ukraine and from GM crops grown in Ukraine. For example, GM potatoes were imported to Ukraine for field research back in the 90's. In conditions that existed in those years, it was impossible to ensure proper control over its use. As a result, GM crops are grown uncontrolled in the Ukrainian fields. Ukrainian producers of agricultural products see the benefits of GMOs in higher yields. Experts estimate that 
from $50 \%$ to $80 \%$ of soybeans grown in Ukraine are genetically modified. There is no official data on this score. Experts explain this by the fact that Ukrainian soybean is consumed in the domestic market, and not for export. In Ukraine, GM is also much less grown potatoes, maize, barley, and also GM cotton. The lack of effective programs for field supervision and seed control encourages agricultural producers to use GM crops. The widespread use of GM seeds in agriculture is hindered by the low level of protection of intellectual property rights in Ukraine. Mainly, it concerns wheat and rapeseed, and hybrid seeds of corn and soybeans are already in the market (Malysh, 2013).

In the light of Ukraine's current integration aspirations to join the European community and the strengthening of agricultural products in its market as a competitive and quality producer, there is a need for an effective mechanism for exercising state control over the turnover of genetically modified organisms. This issue remains unresolved for Ukraine and requires further comprehensive improvement. The first effective steps have already been taken. In particular, the Association Agreement with the EU stipulates that Ukraine should develop an integrated strategy for regulating GMOs. An interesting point is included in this Agreement. In particular, Article 404, which refers to agriculture, states that, among other things, both parties will cooperate to expand the use of biotechnology. In fact, this article paves the way for the liberalization of the existing practice of certification of genetically modified seed stock. This provision justifies the expectations of the agribusiness industry. Ukraine belongs to the perspective markets for transnational corporations for the production of seeds.

It should be recalled that with the accession to the WTO, Ukraine has undertaken certain obligations that can be applied, among other things, to regulate the production of genetically modified products, namely:

- from the date of accession to the WTO, Ukraine undertook to abolish and not reintroduce or apply quantitative restrictions on imports or other non-tariff measures such as licensing, quoting, prohibitions, permits, previous authorization requirements, licensing requirements and other restrictions on such effect that cannot be justified in accordance with the provisions of the relevant WTO Agreement;

Ukraine should apply import licensing according to the rules of the WTO import licensing agreement, which provide for transparency, simplification, and acceleration of procedures but should not exert too restrictive and influential influence on trade;

Ukraine has the right to apply sanitary and phytosanitary measures to protect the life or health of humans, animals, or plants, which must be based on scientific principles and don't create unjustified discrimination or hidden restrictions on trade;

Ukraine should apply technical regulations and standards for the purposes of national security, prevent fraudulent actions, protect the life or health of humans, animals or plants, and protect the environment, on the basis of scientific justification and without creating unnecessary obstacles to trade (Volkov, 2014).

However, in pursuance of this decree, state bodies must develop a number of normative documents but this has not been done. In particular, the state registration of GMOs has not been developed, there is no order of labelling of food products and agricultural raw materials, import and transit of GMOs, provisions on licensing of laboratories, should determine the content of GMOs and others. That is, on November 1, 2007, the decision came into force but it is absolutely not provided.

The Law of Ukraine «On the State Biosafety System for the Creation, Testing, Transportation and Use of GMOs» also outlines the main principles of the state policy in the field of handling GMOs, the main of which are:

- the priority of preserving human health and protecting the environment compared to obtaining economic benefits from the use of GMOs;

- provision of security measures for the creation, research, and practical use of GMOs for economic purposes (Novozhilov, 2008).

On May 13, 2009, the Cabinet of Ministers adopted a decree on mandatory labelling of food products for GMOs, which was long awaited (environmental groups) and was feared (producers). According to the Resolution, all foodstuffs containing GMO of more than $0.1 \%$ volume are subject to labelling. In addition, food products that do not contain GMOs but have been produced using agricultural products containing more than $0.1 \%$ of GMOs should be labelled (this product is called «food produced with the use of GMOs»). In practice, this means that all GM foods need to be labelled since the $0.1 \%$ threshold is the measurement error in the laboratory, determines the content of GMOs.

Products that do not contain GMOs generally containing less than $0.1 \%$ of GMO can be labelled as such that they «do not contain genetically modified organisms ». This information is subject to control (verification) in accordance with the established procedure by the State Committee for Technical Regulation and Consumer Policy. Not labelled GM food in accordance with the above procedure should be removed from circulation (Iaroshevskaya, 2009, p. 18).

We can say that the legislative basis in Ukraine for GMO is undeveloped and seriously lags behind the EU standards.

\section{Conclusions}

The production and consumption of genetically modified foods are growing every year. The study also does not stand still and try to study the influence of GMOs on living organisms, people and the environment as deeply as possible and in detail. In developed countries, clear rules for the production, labelling, 
consumption, and trade of products containing GMOs are developed. Also, the bodies and structures responsible for compliance with all these rules adopted a large number of legislative acts.

Ukraine «on the paper» also seems to have some GMO rules but they are not clear, consistent and nobody follows them because these powers are entrusted to a large number of structures. Due to imperfect legislation and lack of funds, products that are imported are not tested for GMO content, studies are not conducted on the safety of their consumption and cultivation, the reliability of information on labels is not followed. Therefore, in order to ensure an appropriate level of the state regulation, protection, and use of genetically modified products obtained with the help of modern biotechnologies, it is necessary to strictly adhere to the fulfilment of the main criteria:

- adoption and further improvement of the legislation to regulate this field of activity;
- accounting and prevention of the danger of genetic pollution of the environment as a result of the production of genetically modified products;

- determination of economic efficiency from growing GM plants;

- implementation of a transparent GMO registration system and issuing permits for field testing of transgenic plants, limiting plant testing to several years;

- solution of the problem of intellectual property protection in this area and technology transfer;

- determination of the degree of influence of genetically modified products on human health and the biosystem as a whole;

- formation of public opinion, development of environmental education;

- intensification of international cooperation in biotechnology of plants and biosafety.

Ukrainians have the right to know what they consume, and what effect these products have.

\section{References:}

Balasynovich B. \& Iaroshevska Iu. (2010). GMO: the challenges and the experience of legal regulation. Institute for Economic Research and Policy Consulting, $255 \mathrm{p}$.

Blum Ya., Sivolap Yu., Rydiy R. \& Sozinov A. (2006). A new wave of the «green revolution».

Brooks G. \& Blum Ya. (2012). Potential economic and ecological effect from the introduction of modern GM crops into the agricultural production of Ukraine, $88 \mathrm{p}$.

Dromashko S.E. \& others. (2011). Genetically modified organisms and problems of biosecurity. Minsk. State Institution of Education "Researchers Training Institute National Academy of Sciences of Belarus". 70 p.

Iakovleva I. V., Vinogradova S. V. \& Kamionskaia A. M. (2015). State turnover regulation of biotechnological (GM) agricultural products: an analysis of different approaches in the world's practice. Ecological genetic. No 2. P. 21-25. Iaroshevska Yu. (2009). The choice of Ukraine regarding the policy in the field of genetically modified organisms: the EU model or the US? Kiev. Institute of Economic Research and Policy Consulting. 66 p.

Iulevich O.I., Kovtun S.I. \& Gil M.I. (Ed.) (2012). Biotechnology: textbook. Nikolaev. NSAU. 476 p.

Koval L. (2007). Transgenes: salvation or threat. Government courier. No. 90.

Lozinska T. M. (2009). The concept of three-dimensional product typology in public administration of food market development. Actual problems of public administration. №2. P. 117-125.

Makarovskaya V.R. (2008). Administrative and legal regulation of production and consumption of genetically modified foods. Medical Law of Ukraine: the legal status of patients in Ukraine and its legislative support (genesis, development, problems and prospects for improvement). Materials of the II International Scientific and Practical Conference. Lviv. P. 155-159.

Malysh N. (2013). Genetically Modified Organisms in the Food Safety System of Ukraine. The State and the Market. No 2(14) P. 116-122.

Novozhilov O.V. (2008). Legislative and regulatory framework for the use and regulation of the turnover of genetically modified organisms in Ukraine. Genetically Modified Organisms: Problems and Prospects of Use in Ukraine. Moscow. Agrarian Science. P. 15.

Resolution of the Cabinet of Ministers No. 468 of May 13, 2009. On approval of the procedure for labeling food products containing genetically modified organisms or produced with their use and put into circulation.

Stepnova A. \& Berlova H. (2007). About regulation of genetically modified products markets. All about meat. No 6. P. 2-7.

Volkov O. (2014). State regulation of the turnover of GMOs in Ukraine: current status and the blueprint of reforming. Kyiv. USAID Agroinvest. 37 p. 


\section{Виктория БАШУК}

\section{ОСОБЕННОСТИ ГОСУДАРСТВЕННОГО РЕГУЛИРОВАНИЯ ПРОИЗВОДСТВА ГЕНЕТИЧЕСКИ МОДИФИЦИРОВАННОЙ ПРОДУКЦИИ В МИРЕ И В УКРАИНЕ}

Аннотация. Целью данной работы является исследование регулирования использования, потребления и торговли генетически модифицированными организмами в разных странах мира, а также в Украине. Определение международных подходов к оценке риска генетически модифицированной продукции имеет особое значение для международной торговли. Методология. Исследование базируется на данных, взятых из разных источников, начиная с первых упоминаний о генетически модифицированных организмах, заканчивая новейшими полученными данными из разных стран. Цель. Показать, как различные страны по-разному относятся к производству генетически модифицированных продуктов, по-разному их воспринимают и руководствуются разными принципами. Найти пути решения проблем, связанных с введением ГМО в Украине, и сравнить их с другими странами. Результаты. Исследование показало, что в развитых странах разработаны четкие правила производства, маркировки, потребления и торговли продуктами, содержащими ГМО. Также определены органы и структуры, ответственные за соблюдение всех этих правил, принято большое количество законодательных актов, чего нельзя сказать об Украине. В Украине в этом вопросе большой пробел, потому что «на бумаге» тоже вроде присутствуют некоторые правила относительно ГМО, но они не четкие, не последовательные и за их соблюдением никто не следит, так как эти полномочия возложены на большое количество структур. Из-за несовершенства законодательства и отсутствия средств не проверяются продукты, которые импортируются, на содержание ГМО, не проводятся исследования по безопасности их потребления и выращивания, не следят за достоверностью информации на этикетках. Практическое значение. В Украине для обеспечения надлежащего уровня государственного регулирования, защиты и использования генетически модифицированной продукции, полученной с помощью современных биотехнологий, необходимо четко придерживаться выполнения главных критериев: 1) принятие идальнейшее совершенствованиезаконодательства по регулированиюэтой сферыдеятельности; 2) учет и предупреждение опасности генетического загрязнения окружающей среды в результате производства генетически модифицированной продукции; 3) определение экономической эффективности от выращивания ГМ-растений; 4) введение прозрачной системы регистрации ГМО и выдачи разрешений на полевые испытания трансгенных растений, ограничение испытаний растений несколькими годами; 5) решение проблемы защиты интеллектуальной собственности в этой области и трансфера технологий; 6) определение степени влияния генетически модифицированной продукции на здоровье человека и биосистемы в целом; 7) формирование общественного мнения, развитие экологического образования; 8) активизация международного сотрудничества в области биотехнологии растений и биобезопасности. Значение/оригинальность. Украина - большая страна, которая развивается, имеет хороший потенциал и может получить экономическую выгоду от производства генетически модифицированных продуктов, поэтому необходимо в ближайшее время заполнить все пробелы в этом вопросе, чтобы занять свое место в сфере генетически модифицированных продуктов. 